\title{
Correction: Beristain Iraola et al. User Centered Virtual Coaching for Older Adults at Home Using SMART Goal Plans and I-Change Model. Int. J. Environ. Res. Public Health $2021,18,6868$
}

\author{
Andoni Beristain Iraola 1,2,*(D), Roberto Álvarez Sánchez ${ }^{1,2} \mathbb{D}$, Santiago Hors-Fraile ${ }^{3}$, Despoina Petsani $4 \mathbb{D}^{\mathbb{D}}$, \\ Michail Timoleon ${ }^{4}$, Unai Díaz-Orueta ${ }^{5}$, Joanne Carroll ${ }^{6}$, Louise Hopper ${ }^{6} \mathbb{D}$, Gorka Epelde ${ }^{1,2} \mathbb{D}$, Jon Kerexeta ${ }^{1,2} \mathbb{D}$, \\ Panagiotis D. Bamidis ${ }^{4,+} \mathbb{D}$ and Evdokimos $I$. Konstantinidis $4,7,+\mathbb{D}$
}

check for updates

Citation: Beristain Iraola, A.; Álvarez Sánchez, R.; Hors-Fraile, S.; Petsani,

D.; Timoleon, M.; Díaz-Orueta, U.;

Carroll, J.; Hopper, L.; Epelde, G.;

Kerexeta, J.; et al. Correction: Iraola et al. User Centered Virtual Coaching for Older Adults at Home Using SMART Goal Plans and I-Change Model. Int. J. Environ. Res. Public Health 2021, 18, 6868. Int. J. Environ. Res. Public Health 2022, 19, 2116 https:/ / doi.org/10.3390/ijerph 19042116

Received: 27 October 2021

Accepted: 3 November 2021

Published: 14 February 2022

Publisher's Note: MDPI stays neutral with regard to jurisdictional claims in published maps and institutional affiliations.

Copyright: (C) 2022 by the authors Licensee MDPI, Basel, Switzerland. This article is an open access article distributed under the terms and conditions of the Creative Commons Attribution (CC BY) license (https:// creativecommons.org/licenses/by/ $4.0 /)$.
1 Digital Health \& Biomedical Technologies Department, Vicomtech Foundation, Basque Research and Technology Alliance (BRTA), Mikeletegi 57, 20009 San Sebastián, Spain; ralvarez@vicomtech.org (R.Á.S.); gepelde@vicomtech.org (G.E.); jkerexeta@vicomtech.org (J.K.)

2 e-Health Department, Biodonostia Health Research Institute, Paseo Dr Begiristain s/n, 20014 San Sebastián, Spain

3 Salumedia Labs, Research Division of Adhera Health, Inc., Palo Alto, CA 94304, USA; shors@adherahealth.com

4 Lab of Medical Physics and Digital Innovation, School of Medicine, Aristotle University of Thessaloniki, 54124 Thessaloniki, Greece; despoinapets@gmail.com (D.P.); mtimoleon@auth.gr (M.T.); pdbamidis@gmail.com (P.D.B.); evdokimosk@gmail.com (E.I.K.)

5 Department of Psychology, Maynooth University, Maynooth W23 F2H6, Co. Kildare R51, Ireland; unai.diazorueta@mu.ie

6 School of Psychology, Dublin City University, Dublin 9, Ireland; joanne.carroll@dcu.ie (J.C.); louise.hopper@dcu.ie (L.H.)

7 WITA SRL, 38123 Trento, Italy

* Correspondence: aberistain@vicomtech.org

+ These authors contributed equally to this work.

The author would like to change the authorship in the previous publication [1].

\section{Addition of Authors}

Santiago Hors-Fraile, Despoina Petsani, Michail Timoleon, Unai Díaz-Orueta, Joanne Carroll, Louise Hopper, Gorka Epelde, Jon Kerexeta, Panagiotis D. Bamidis, Evdokimos I. Konstantinidis were not included as authors in the published article. The corrected Author Contributions Statement appears here. The authors apologize for any inconvenience caused and state that the scientific conclusions are unaffected. The original article has been updated.

Author Contributions: Conceptualization: A.B.I., R.Á.S., S.H.-F., D.P., U.D.-O., G.E., P.D.B. and E.I.K.; data Curation: D.P.; funding acquisition: A.B.I., G.E., P.D.B. and E.I.K.; investigation: A.B.I., R.Á.S., J.C., L.H., J.K., P.D.B. and E.I.K.; methodology: A.B.I., R.Á.S., M.T., U.D.-O., J.C. and L.H.; project administration: A.B.I. and E.I.K.; resources: A.B.I., R.Á.S., J.C. and L.H.; software: A.B.I., R.Á.S., M.T. and J.K.; supervision: A.B.I., L.H., P.D.B. and E.I.K.; validation: J.C. and L.H.; visualization: J.K.; writing-original draft: A.B.I. and R.Á.S.; writing-review and editing: A.B.I., R.Á.S. and J.K. All authors have read and agreed to the published version of the manuscript.

\section{Reference}

1. Beristain Iraola, A.; Álvarez Sánchez, R.; Hors-Fraile, S.; Petsani, D.; Timoleon, M.; Díaz-Orueta, U.; Carroll, J.; Hopper, L.; Epelde, G.; Kerexeta, J.; et al. User Centered Virtual Coaching for Older Adults at Home Using SMART Goal Plans and I-Change Model. Int. J. Environ. Res. Public Health 2021, 18, 6868. [CrossRef] [PubMed] 